Short Communications

\title{
Effect of Growth Temperature upon Heat Sensitivity in Saccharomyces cerevisiae
}

\author{
E. Fintan Walton ${ }^{1,2}$ and John R. Pringle ${ }^{1}$ \\ Division of Biological Sciences, The University of Michigan, Ann Arbor, Michigan 48109, USA ${ }^{1}$ \\ and Department of Genetics, University of Dublin, Trinity College, Dublin 2, Ireland ${ }^{2}$
}

\begin{abstract}
The resistance of exponentially growing yeast cells to killing by exposure to $52^{\circ} \mathrm{C}$ increased markedly as the growth temperature was increased. Identical killing curves were obtained for cells suspended in growth medium or in $0.9 \%$ saline. Cells resistant to killing at $52^{\circ} \mathrm{C}$ were quite sensitive to killing at slightly higher temperatures. These results suggest a primary role for membrane damage in the mechanism of heat killing.
\end{abstract}

Key words: Yeast - Saccharomyces cerevisiae - Heat killing - Membrane damage - Genetic damage Growth temperature.

Although many studies have been made of thermal damage to yeast and other microorganisms, the exact mechanisms of killing by temperatures $12-20^{\circ} \mathrm{C}$ above the maximum for growth remain obscure (Inniss, 1975; Welker, 1976; Hurst, 1977). While developing a mutant selection procedure (Walton et al., 1979) that exploits the difference in heat resistance between exponentially growing and stationary phase yeast cells (SchenbergFrascino and Moustacchi, 1972; Parry et al., 1976), we observed that the heat sensitivity of exponentially growing cells varied dramatically as a function of growth temperature. This observation seems to have important implications as to the mechanism of heat killing.

\section{Materials and Methods}

All experiments utilized the prototrophic haploid strain of Saccharomyces cerevisiae C276-4Aa (Walton et al., 1979). Cultures were grown to exponential phase (approximately $10^{7} \mathrm{cells} / \mathrm{ml}$ ) in the

Address for offprints : J. R. Pringle, Division of Biological Sciences. The University of Michigan, Ann Arbor, Michigan 48109, USA rich liquid medium YM-1 (Walton et al., 1979) on rotary shakers at $23^{\circ} \mathrm{C}, 30^{\circ} \mathrm{C}$, or $36^{\circ} \mathrm{C}$. From each exponential culture, a $2 \mathrm{ml}$ portion was transferred to a separate prewarmed test tube in a water bath at $52^{\circ} \mathrm{C}$. Samples were taken from these test tubes at $1 \mathrm{~min}$ intervals, diluted in sterile distilled water at $0^{\circ} \mathrm{C}$ (to avoid any possibility of "liquid-holding recovery" - see Schenberg-Frascino, 1972), sonicated to break up clumps (Walton et al., 1979), and plated on YEPD plates (Walton et al., 1979) to determine the numbers of viable cells. Platings were made in duplicate within $1 \mathrm{~h}$ after sampling, and colonies were scored after $4-5$ days incubation at $23^{\circ} \mathrm{C}$. In a separate but similar experiment, $2 \mathrm{ml}$ portions from a culture growing exponentially at $36^{\circ} \mathrm{C}$ were transferred to prewarmed test tubes in water baths at $52^{\circ} \mathrm{C}, 55^{\circ} \mathrm{C}, 57^{\circ} \mathrm{C}$, or $59^{\circ} \mathrm{C}$. Sampling, plating, and scoring of plates were as just described. In another experiment, samples taken from the exponentially growing cultures were filtered through sterile Millipore filters (type HAWP, $0.45 \mu \mathrm{m}$ pore size) and washed with $0.9 \%(\mathrm{w} / \mathrm{v}) \mathrm{NaCl}$ solution at the temperature at which the cells had been grown. Each filter was then quickly transferred to $2 \mathrm{ml}$ of $0.9 \% \mathrm{NaCl}$ solution at $52^{\circ} \mathrm{C}$ and shaken vigorously for a few seconds. The resuspended cells were then poured into a second prewarmed test tube, and incubation was continued at $52^{\circ} \mathrm{C}$. Sampling, plating, and scoring of plates were as described above.

\section{Results}

Growth of yeast cells at $23^{\circ} \mathrm{C}, 30^{\circ} \mathrm{C}$, or $36^{\circ} \mathrm{C}$ prior to exposure to $52^{\circ} \mathrm{C}$ produced dramatic differences in heat sensitivity (Fig. 1A). A culture growing exponentially at $23^{\circ} \mathrm{C}$ had a 1000 -fold decrease in the number of cells capable of forming colonies during an 8 min exposure to $52^{\circ} \mathrm{C}$, while cultures growing at $30^{\circ} \mathrm{C}$ and $36^{\circ} \mathrm{C}$ had 30 -fold and 2-fold decreases, respectively.

In order to determine whether these results had been influenced by the presence of nutrients in the suspending medium, cells grown at $23^{\circ} \mathrm{C}$ or $36^{\circ} \mathrm{C}$ were exposed to $52^{\circ} \mathrm{C}$ in $0.9 \% \mathrm{NaCl}$ rather than in growth medium. Results indistinguishable from those of Fig. 1A were obtained (data not shown).

In order to determine the extent of the heat resistance of the cells that had been grown at $36^{\circ} \mathrm{C}$, such cells were exposed to $52^{\circ} \mathrm{C}, 55^{\circ} \mathrm{C}, 57^{\circ} \mathrm{C}$, and $59^{\circ} \mathrm{C}$. More rapid losses of viability were observed at the 


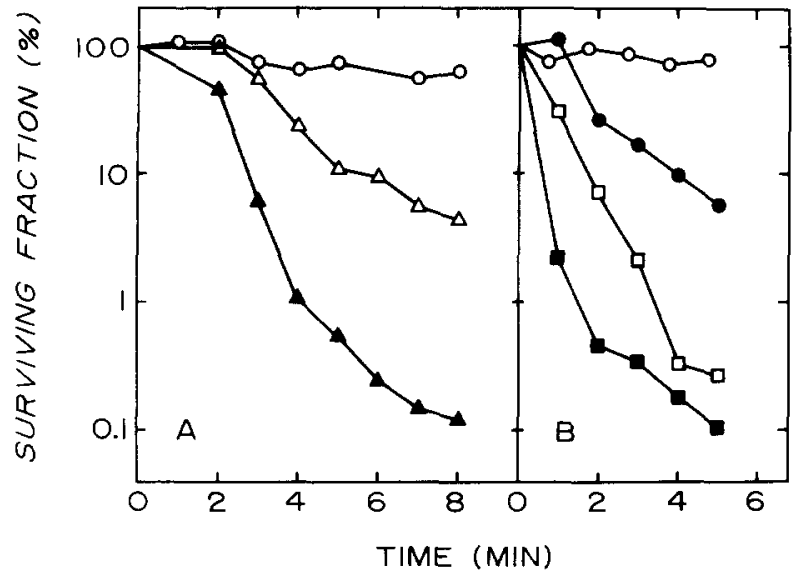

Fig. $1 \mathrm{~A}$ and B. Kinetics of killing of yeast cells during incubation at elevated temperatures in growth medium. A Cells growing exponentially at $23^{\circ} \mathrm{C}(\Delta), 30^{\circ} \mathrm{C}(\Delta)$, or $36^{\circ} \mathrm{C}(\mathrm{O})$ were incubated at $52^{\circ} \mathrm{C}$. $B$ Cells growing exponentially at $36^{\circ} \mathrm{C}$ were incubated at $52^{\circ} \mathrm{C}(\mathrm{O})$, $55^{\circ} \mathrm{C}(\bullet), 57^{\circ} \mathrm{C}(\square)$, or $59^{\circ} \mathrm{C}(\mathbf{\square})$

higher temperatures (Fig. 1B), but even at the higher temperatures, $23^{\circ}$-grown cells were much more sensitive than $36^{\circ}$-grown cells (data not shown).

\section{Discussion}

Effects of growth temperature on heat sensitivity similar to those described here have been reported also for bacteria (Elliker and Frazier, 1938; Welker, 1976; Yatvin, 1977). Among the hypotheses that have been advanced to account for heat killing, the idea that damage to cellular membranes is the primary lethal event provides the readiest explanation for these observations. Many organisms respond to variations in environmental temperature by adjusting the lipid and protein composition of their membranes in such a way as to achieve "homeoviscous adaptation" (Esser and Souza, 1976; Arthur and Watson, 1976; Welker, 1976). It seems likely that Saccharomyces cerevisiae also achieves an effective homeoviscous adaptation (Chang and Matson, 1972; Hunter and Rose, 1972; Shimizu and Katsuki, 1975). It also seems likely that such adjustments of membrane composition would cause the membranes from cells grown at higher temperatures to be less susceptible to disruption and lysis by heat shock, and there is direct evidence to this effect (Chang and Matson, 1972; Hagler and Lewis, 1974; Welker, 1976). Moreover, bacterial mutants that do not achieve a normal membrane lipid composition during growth at higher temperatures are much more sensitive to heat killing than are the parent strains (Esser and Souza, 1976; Yatvin, 1977).
The mechanism by which heat-induced membrane disruption leads to cell death may be more complex than a simple lysis of the cell. For example, the disruption of membrane organization might inactivate essential membrane-bound enzymes (Welker, 1976). Alternatively, membrane disruption might lead to a breakdown in the compartmentation of cellular hydrolases, which could then inflict lethal damage on the cell. Indeed, there is evidence that the genetic damage observed after exposure to heat is largely enzymatic in origin (Welker, 1976). Thus, it may be possible to reconcile the evidence that membrane damage is important in heat killing with the seemingly strong evidence (Schenberg-Frascino and Moustacchi, 1972; Evans and Parry, 1975; Tyrrell, 1976; Welker, 1976) that genetic damage is also involved.

Acknowledgements. We thank J. Parry and E. Moustacchi for their prompt responses to early requests for information about heat killing in yeast, B.L.A. Carter for the hospitality of his laboratory, and B. S. Mitchell for her criticism. This work was supported by Public Health Service grant GM23936, by Institutional Research Grant No. IN-40P to the University of Michigan from the American Cancer Society, and by a travel grant to E. F. W. from the American-Irish Foundation.

\section{References}

Arthur, H., Watson, K.: Thermal adaptation in yeast: growth temperatures, membrane lipid, and cytochrome composition of psychrophilic, mesophilic, and thermophilic yeasts. J. Bacteriol. 128, 56-68 (1976)

Chang, S. B., Matson, R. S.: Membrane stability (thermal) and nature of fatty acids in yeast cells. Biochem. Biophys. Res. Commun. 46, 1529 - 1535 (1972)

Elliker, P. R., Frazier, W. C.: Influence of time and temperature of incubation on heat resistance of Escherichia coli. J. Bacteriol. 36, $83-98(1938)$

Esser, A. F., Souza, K. A.: Growth temperature and the structure of the lipid phase in biological membranes. In: Extreme environments: mechanisms of microbial adaptation (M. R. Heinrich, ed.), pp. 283-294. New York: Academic Press 1976

Evans, W. E., Parry, J. M.: The genetic effects of elevated temperature in the yeast, Saccharomyces cerevisiae. Heredity 35, 347359 (1975)

Hagler, A. N., Lewis, M. J.: Effect of glucose on thermal injury of yeast that may define the maximum temperature of growth. $J$. Gen. Microbiol. 80, 101-109 (1974)

Hunter, K., Rose, A. H.: Lipid composition of Saccharomyces cerevisiae as influenced by growth temperature. Biochim. Biophys. Acta 260, 639-653 (1972)

Hurst, A. : Bacterial injury: a review. Can. J. Microbiol. 23, 935-944 (1977)

Inniss, W. E. : Interaction of temperature and psychrophilic microorganisms. Annu. Rev. Microbiol. 29, 445-465 (1975)

Parry, J. M., Davies, P. J., Evans, W. E.: The effects of "cell age" upon the lethal effects of physical and chemical mutagens in the yeast, Saccharomyces cervisiae. Molec. Gen. Genet. 146, 27-35 (1976)

Schenberg-Frascino, A.: Lethal and mutagenic effects of elevated temperature on haploid yeast. II. Recovery from thermolesions. Molec. Gen. Genet. 117, $239-253$ (1972) 
Schenberg-Frascino, A., Moustacchi, E.: Lethal and mutagenic effects of elevated temperature on haploid yeast. I. Variations in sensitivity during the cell cycle. Molec. Gen. Genet. 115, $243-$ 257 (1972)

Shimizu, I., Katsuki, H.: Effect of temperature on ergosterol biosynthesis in yeast. J. Biochem. (Tokyo) 77, $1023-1027$ (1975)

Tyrrell, R. M.: Synergistic lethal action of ultraviolet-violet radiations and mild heat in Escherichia coli. Photochem. Photobiol. 24, 345-351 (1976)

Walton, E. F., Carter, B. L. A., Pringle, J. R. : An enrichment method for temperature-sensitive and auxotrophic mutants of yeast. Molec. Gen. Genet. 171, 111-114 (1979)
Welker, N. E.: Microbial endurance and resistance to heat stress. In The survival of vegetative microbes (T. R. G. Gray, J. R. Postgate, eds.), pp. 241-277. Cambridge, New York: Cambridge University Press 1976

Yatvin, M. B.: The influence of membrane lipid composition and procaine on hyperthermic death of cells. Int. J. Radiat. Biol. 32 , $513-521$ (1977)

Received May 29, 1979 